\title{
Structural analysis of a fragmented area in Minas Gerais State, Brazil
}

\author{
NATÁLIA V. SALOMÃO ${ }^{1}$, EVANDRO L.M. MACHADO ${ }^{1}$, RAFAELLA S. PEREIRA ${ }^{1}$, GERALDO W. \\ FERNANDES ${ }^{2}$, ANNE P.D. GONZAGA ${ }^{1}$, DANIELLE P. MUCIDA ${ }^{1}$ and LEOVANDES S. DA SILVA ${ }^{1}$ \\ ${ }^{1}$ Universidade Federal dos Vales do Jequitinhonha e Mucuri, Departamento de Engenharia Florestal, \\ Rodovia MGT 367, Km 583, n 5000, Alto da Jacuba, 39100-000 Diamantina, MG, Brazil \\ ${ }^{2}$ Universidade Federal de Minas Gerais, Instituto de Ciências Biológicas, Departamento de Ecologia \\ e Evolução, Av. Presidente Antônio Carlos, 6627, 30161- 901 Belo Horizonte, MG, Brazil
}

Manuscript received on November 28, 2016; accepted for publication on January 29, 2018

\begin{abstract}
The theory of landscape ecology applied to the methods of spatial analysis helps to understand changes in the structure of forest remnants. In view of this theory, the objective of the present study was to analyze the structure of a fragmented area between the years 1979 and 2015 through calculation of landscape metrics for arboreal, shrubby and herbaceous vegetation classes. Vegetation classes were classified with visits to the field, interpretation of aerial photographs from 1979 and supervised classification of Landsat 8 from 2015. The metrics calculated for each class were area and total number of fragments, total edge and average connectivity among the fragments. The analysis of structure found that it changed negatively due to an increase in the number of small fragments, which increased the intensity of edge effects and reduced connectivity between fragments for all classes.
\end{abstract}

Key words: Landscape, ecology, tree, shrub, herb, metrics.

\section{INTRODUCTION}

The landscape, whose heterogeneity is principally determined by the relationship between society and nature, can be considered a spatial unit in which its structure is a result of the complex interactions between man and the natural environment, featuring a structure fragmented by different uses (Goerl et al. 2011). Within this context, the analysis of landscape structure is essential for understanding the impacts of anthropic alterations (Lang and Blaschke 2009).

Correspondence to: Natália Viveiros Salomão

E-mail: viveiros.natalia@yahoo.com.br
There are two main approaches to landscape ecology: the geographical approach, which emphasizes the study of man's influence on the landscape and land management; and the ecological approach, which emphasizes the importance of spatial configuration on ecological processes and the importance of these interactions in terms of biological conservation (Metzger 2001). Fragmentation is a common issue to both approaches and exerts a major influence on current and future landscape models (Gomide and Lingnau 2008), since it is responsible for many physical and ecological changes such as habitat loss and isolation. As forest landscapes become fragmented, 
species populations become reduced, migration and dispersal patterns are modified and habitats become exposed to different external conditions (Nascimento and Laurance 2006).

According to Forman and Godron (1986), landscape ecology considers the structure, function and alteration of ecosystems. Structure is related to the spatial interactions between distinct ecosystems, and involves analyzing the distribution of energy, materials and species in relation to the size, shape, quantity, type and configuration of ecosystem components. Function refers to the interaction among spatial elements, that is, the flow of energy, materials and species among the components of the ecosystem. Alteration is related to changes in the structure and function of the ecological mosaic, which creates modifications in space and time capable of producing heterogeneity that controls the movement and flow of organisms, matter and energy.

The constituent elements of the spatial structure of a landscape are distinguished as the matrix, corridors and patches (Forman 1995). According to Burel and Baudry (2002), a landscape pattern consists of a mosaic formed of patches connected by corridors forming a network, which maintains an edge at its limits that interacts with the matrix. The matrix is the dominant controlling element of the functioning and dynamics of a landscape with the patches representing the predominant location of the meeting of species, which are connected by corridors (Forman 1995).

The quantification of landscape structure has been facilitated by global information systems (GISs), which provide spatial data processing and analysis (Ferraz and Vettorazzi 2003). Until the 1980s, information on soil occupation was based more on the method of visual interpretation, in particular for the execution of large-area mapping projects (Skole and Tucker 1993). Currently, supervised digital classification of images is the most widely used method for quantitative analysis of data and is based on the use of algorithms to determine the pixels that represent values for a certain class and requires previous knowledge of the number of classes of use and ground cover contained in an image (Rudorff et al. 2007).

Area and edge effects are the most important factors influencing fragmented communities (Zuidema et al. 1996). Area effects are related to environmental changes that occur due to fragment isolation and are proportional to the area of the fragment (Nascimento and Laurance 2006). Edge effects, on the other hand, are caused by different gradients of physical and biotic changes near the border of forests and, therefore, are proportional to the distance between fragments (Zuidema et al. 1996).

Within the context of landscape ecology, the objective of this work was to quantify and analyze changes in the spatial structure of the landscape during the periods of 1979 and 2015, for a fragmented landscape in the municipality of Conceição do Mato Dentro, in the state of Minas Gerais, Brazil, in relation to the number and size of the area of the fragments, total edge and mean of the connectivity between fragments. For this purpose, cartographic material, satellite images and class metrics were used as a basis in Fragstats 4.2, since the study was analyzed through vegetation classes. Considering the above, the hypothesis tested by this work was that fragmentation of the area has significantly altered the spatial structure of the landscape, and so the following specific question was addressed: What are the possible effects on the landscape due to the alteration in the landscape structure?

\section{MATERIALS AND METHODS}

\section{DESCRIPTION OF THE STUDY AREA}

The study was conducted within the municipality of Conceição do Mato Dentro in the state of Minas Gerais, Brazil. According to the classification of 
Köppen (1900), the climate of the region is tropical of altitude, which is characterized by altitudes above $500 \mathrm{~m}$, mild temperatures between $18^{\circ} \mathrm{C}$ and $26^{\circ} \mathrm{C}$ and annual temperature amplitude between $7^{\circ} \mathrm{C}$ and $9^{\circ} \mathrm{C}$. The altitude of the area varies from 679 to 1472 meters and the landscape comprises a transition area between two Brazilian domains: The Cerrado, one of the richest Savannas in the world (Assunção and Felfili 2004), which is comprised of shrubby and herbaceous vegetation, and the Atlantic Forest, with is comprised of woody (tree) vegetation.

The classification was performed after processing aerial photographs from 1979 and Landsat 8 satellite image from 2015. The metrics were calculated using the free software Fragstats 4.2. This program allows the calculation of metrics for spatial description of the landscape and therefore is unique in the field of landscape ecology as it is able to provide numerous metrics in a single package (Moraes et al. 2015).
PROCESSING AND CLASSIFICATION OF THE IMAGES

Mosaic of aerial photographs (flight 12 July 1979 to 27 October 1979)

A mosaic was created from a combination of aerial photographs taken in the year 1979 using the tool "mosaiking" of the software Envi 4.5. Seventeen aerial photographs provided by the Instituto de Geociências Casa da Glória (IGC) were georeferenced in ArcGis 10.3.

Visual interpretation of the mosaic

The visual interpretation of the mosaic (Fig. 1) was based on the identification key for forest fragments proposed by Panizza and Fonseca (2011). The forest fragments were classified according to the parameters of intensity of color (tone), saturation, texture and shape defined in the mosaic clippings. The visual interpretation of the mosaic resulted in the recognition of three vegetation types: woody

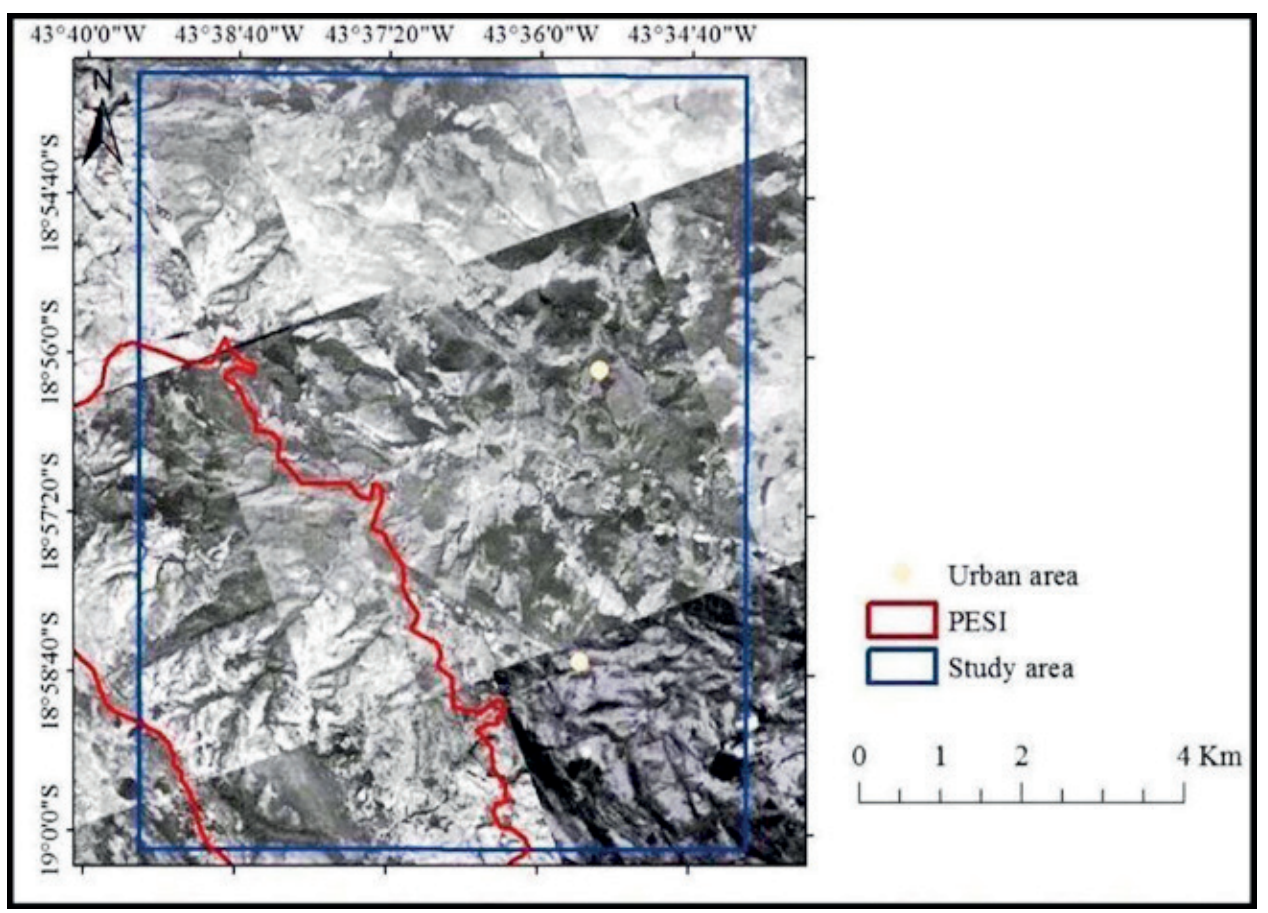

Figure 1 - Mosaic of aerial photographs of the study area including the delimitation of Parque Estadual Serra do Intendente (PESI) in the year 1979. 
(tree) vegetation (Fig. 2a); shrubby vegetation (Fig. 2b) and herbaceous vegetation (Fig. 2c).

\section{Processing the image from Landsat 8, 2015}

For the analysis of the use and occupation of the land of the study area, an image from the Landsat 8 satellite taken on 18 July, 2015 was used. The image was rectified through the polynomial model of geometric correction (registration). In this model, polynomial functions are determined using correction control points, regardless of where the distortions are determined, and modeled independently (Silva et al. 2009). For a spatial reference, the geocover of the state of Minas Gerais in 2010 was used to register the image. This process was performed using the collection of corresponding control points between the two images, which was done with tool "registration" in the software Envi 4.5.

\section{Supervised classification of Landsat 8}

Supervised classification for making a map of use and occupation of the land (Fig. 3) was developed with prior knowledge of the sample points obtained during fieldwork in July 2015. The thematic classes established as a result of this visit were: arboreal vegetation comprised of native vegetation of higher areas of Atlantic Forest; shrub vegetation comprised of native and non-native vegetation of the Cerrado; herbaceous vegetation cover of native and exotic plants; and exposed soil represented by the absence of vegetation.

Finally, the accuracy of the data obtained in the supervised classification was measured and assessed. The points collected in the field were entered and analyzed within the accuracy indices of "global accuracy" and "Kappa" as described by Bolfe et al. (2004). These indices were calculated in the software Envi 4.5 from the confusion matrix generated by the option "post classification" for comparing the regions of interest classified on the image with the classification observed in the field. The result generated an overall accuracy $93 \%$ and a Kappa value of $86 \%$, meaning the classification was satisfactory.

\section{CALCULATION OF LANDSCAPE METRICS}

After the visual interpretation of the mosaic and the supervised classification of the Landsat 8 satellite image, we calculated class metrics using the software Fragstats 4.2.

The following metrics were analyzed for the vegetation classes: fragment metrics (size and number of fragments); edge metrics (total edges); and nearest neighbor metrics (average connectivity

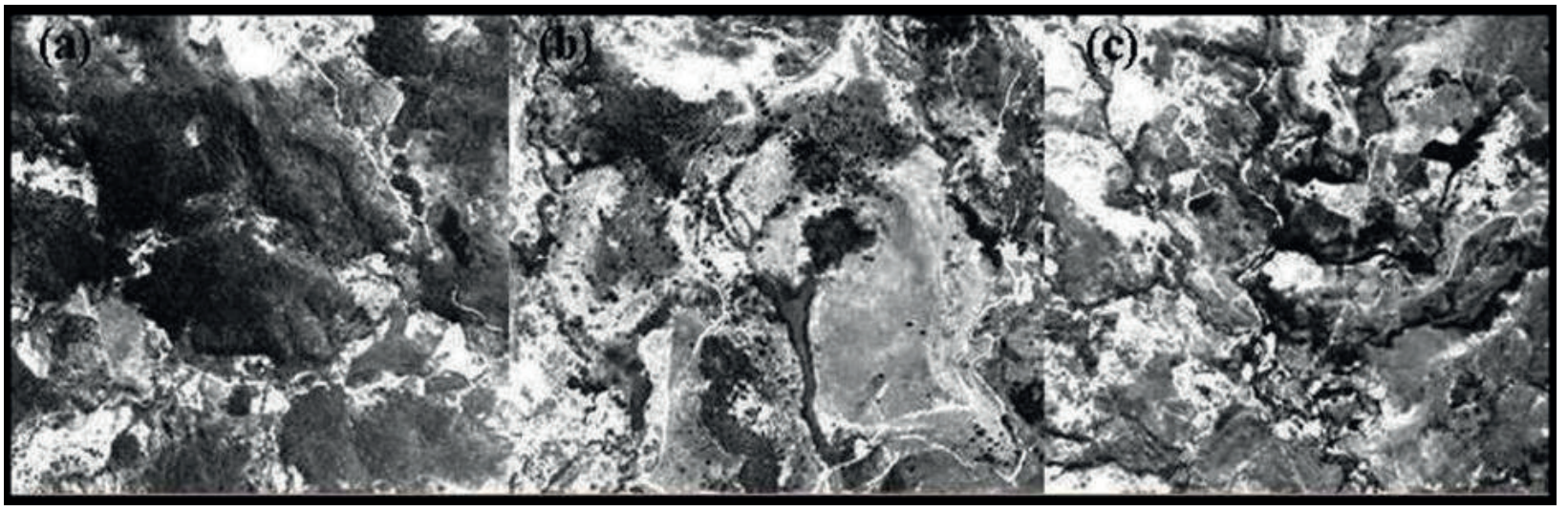

Figure 2 - (a) Arboreal (woody, tree) vegetation represented by fine-grained dark color with an irregular appearance; (b) Shrubby vegetation represented by fine-grained dark color, but lighter than arboreal vegetation, average saturation, and an irregular appearance; (c) Herbaceous vegetation defined by finegrained mid-tone color, low saturation, and an irregular appearance. 


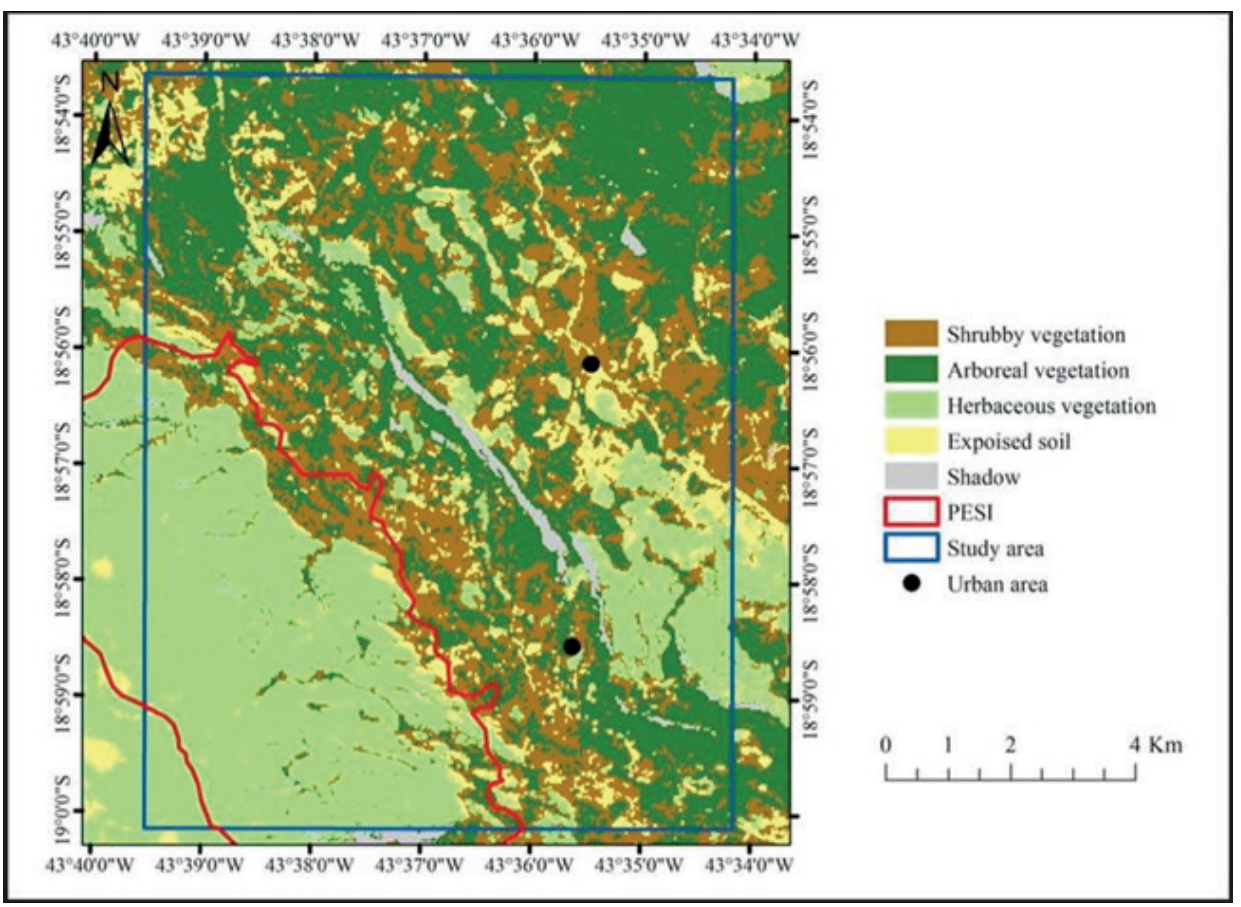

Figure 3 - Use and occupation of the soil in the study area in the year 2015.

between fragments). All metrics resulted in natural numbers, however, certain calculations are more complex and resulted in perimeters being defined in meters and areas defined in hectares (Moraes et al. 2015).

The size of forest fragments was classified as small for fragments with areas less than 50 hectares and large for fragments with areas above 50 hectares (Pirovani et al. 2014). For the edge metric, associated with the intensity of the edge effect, classes that had the largest total distance of edges (TE) were also considered to have a greater intensity of edge effect (Cabacinha et al. 2010). The classes with lower isolation values had higher average connectivity between fragments (Cabacinha et al. 2010).

\section{RESULTS}

\section{LANDSCAPE STRUCTURE BETWEEN THE YEARS 1979 AND 2015}

Considering the fragmentation of the vegetation classes, there was a reduction in arboreal (woody, tree) vegetation in 70 fragments (Table I). On the other hand, there was a significant increase in shrubby vegetation in 986 fragments, while herbaceous vegetation showed little variation, with an increase in 149 fragments (Table I).

A significant increase in total edges for all of the vegetation classes was observed between the years 1979 and 2015. The arboreal vegetation had the greatest intensity of edge effect with an increase of 778.046 meters of edges, followed by shrubby vegetation with an increase of 138.232 meters and herbaceous vegetation with the lowest increase with 10.818 meters of edge (Table I).

A reduction in the average connectivity for all classes was observed as shown by the increased insulation index. Whereas arboreal and herbaceous classes had a significant increase in isolation rates, to 0.2701 and 0.2521 , respectively, shrubby vegetation increased to only 0.0207 (Table I).

According to fragment area, in 1979 all fragments $(100 \% ; \mathrm{n}=798)$ were less than 50 
TABLE I

Vegetation classes and the metrics of "number of fragments", "total edges" and "connectivity" for the fragmented area in the municipality of Conceição do Mato Dentro (Minas Gerais) for the years of 1979 and 2015.

\begin{tabular}{cccccc}
\hline \multirow{2}{*}{ Metrics } & & \multicolumn{3}{c}{ Classes of vegetation } & \multicolumn{2}{c}{ Total for the area } \\
\cline { 3 - 6 } & & Trees & Shrubs & \multicolumn{2}{c}{ Herbs } \\
\hline Number of Fragments & 1979 & 504 & 236 & 58 & 798 \\
(Percentage) & 2015 & 434 & 1222 & 207 & 1863 \\
Total edge (meters) & 1979 & 3.929 & 1.862 & 180 & 5.971 \\
Average connectivity & 2015 & 781.975 & 140.094 & 10.998 & 933.067 \\
& 1979 & 0.2256 & 0.1662 & 0.1627 & 0.5545 \\
\hline
\end{tabular}

hectares, while in the year 2015, 99.57\% $(n=1855)$ were less than a 50 hectares (Table II).

\section{DISCUSSION}

Among the classes of vegetation evaluated, a class shrubby vegetation of the Cerrado exhibited a significant increase in the number of fragments (Table I). The increased fragmentation of the Cerrado is likely due to the influence of agriculture and livestock and the exotic herbaceous invasion such as Brachiaria decumbens, which has been observed in the field. Until recently, livestock in the region of the Cerrado has relied extensively on native vegetation, which is low in productivity. In recent years, however, species of African grasses, mainly Brachiaria decumbens, have been intentionally introduced to provide increased productivity (Durigan et al. 1998).

Invasive African grasses are the greatest agents causers of fragmentation in the shrub and herbaceous classes (Cerrado) due to the fire cycle (Klink and Machado 2005) and their extreme aggressiveness in invading areas of this biome (Barbosa et al. 2008). For the formation of pastures, areas of Cerrado are cleared, burned and then planted with African grasses (Klink and Machado 2005). Although the Cerrado is a fire adapted ecosystem, the use of fire to open virgin areas and to stimulate regrowth of pastures is extremely detrimental to the structure of the area as frequent fires adversely affect the establishment of trees and shrubs (Hoffmann and Moreira 2002).

With respect to the edge metric, the size and shape of fragments are intrinsically associated with the edge and influence the level of impact caused by the edge effect. The shape, associated with the size, is responsible for the configuration of the landscape and its relationship with the edge effect, which alters the biotic and abiotic conditions of fragments and the species occurring therein (Vidolin et al. 2011). Although smaller fragments have more regular shapes, they are more susceptible to edge effects, since smaller fragments have smaller interior-edge ratios and thus experience a more intense edge effect in the structuring the landscape (Juvanhol et al. 2011).

Due to the large number of small fragments (Table II) and the high amount of total edge (Table I), arboreal class (woody) vegetation experienced a more intense edge effect, while herbaceous class, due to the lower number of small fragments (Table II) and lower total edge (Table I), experienced a less intense edge effect (Vidolin et al. 2011) from 1979 to 2015. Although more fragmented, the shrubby class had only $30 \%$ of its total area distributed in small fragments (Table II), indicating a less intense edge effect than for arboreal class.

Although the herbaceous class exhibited a lower intensity of edge effect, as observed in Table II, the structure of this community can be 
TABLE II

Vegetation classes and the metric "size of fragments", for the fragmented area in the municipality of Conceição do Mato Dentro (Minas Gerais) for the years 1979 and 2015.

\begin{tabular}{|c|c|c|c|c|c|}
\hline \multirow{2}{*}{ Metrics } & & \multicolumn{3}{|c|}{ Classes of vegetation } & \multirow{2}{*}{ Total } \\
\hline & & Trees & Shrubs & Herbs & \\
\hline \multirow{2}{*}{$\begin{array}{l}\text { Quantity of small fragments } \\
\qquad(<50 \mathrm{ha})\end{array}$} & 1979 & 504 & 236 & 58 & 798 \\
\hline & 2015 & 431 & 1218 & 206 & 1855 \\
\hline $\begin{array}{l}\text { Number of large fragments } \\
\qquad(>50 \mathrm{ha})\end{array}$ & 2015 & $3(1241,8594)$ & $4(2733,2818)$ & $1(619,5889)$ & $8(4594,273)$ \\
\hline
\end{tabular}

severely affected since the edge effect in the herbaceous class can increase the number of exotic and invasive herbaceous species (Scariot 2000). Herbaceous plants are physiologically tolerant to new environmental conditions and are comprised of mostly species common to sunny environments, and so tend to increase in density in border areas due to the high incidence of light to the understory (Carvalho and Pires 2008). The accumulation of herbaceous species on the borders can lead to a reduction in the number of tree and shrub species due to changes in the processes of seed germination and seedling establishment (Scariot 2000).

Analyzing the vegetation structure of cerrado fragments, Carmo et al. (2011), found that disturbance caused by exotic grass cover and the occurrence of livestock affect the structure of the plant community and lead to fragmentation of the area, thereby increasing the edge effect and, consequently, causing the loss of native species. Thus, for both works an increase in the mortality of native species near the edge, as well as a simultaneous increase in exotic and climate-tolerant species, were expected in the altered environment (Muller et al. 2009). It can be seen from these studies that edges of fragments represent an area for the development of species of exotic grasses that successfully inhabit the ecotonal environment.

Ribeiro (2008) also found alterations to the structure of plant communities due to an increased edge effect in fragmented areas of cerrado. Their results showed a clear influence of the edge effect since the vegetation structure and the level of aggregation of the analyzed individuals were different between the interiors and edges of the analyzed fragments.

The average connectivity with the nearest neighbor expressed by the degree of isolation of the fragments interferes significantly with landscape structure as it affects gene flow between forest fragments (Viana and Pinheiro 1998). The reduction in average connectivity between the fragments for the arboreal and herbaceous classes was due to the increase in number of small fragments in both classes (Table II). The connectivity between fragments in the shrub class remained almost the same between the years 1979 and 2015 as most of its total area was distributed in large fragments (Table II). According to Juvanhol et al. (2011), smaller fragments can have lower connectivity among themselves since they have a higher degree of isolation, while larger fragments have great connectivity as a result of their lower degree of isolation.

Inananalysis offragments ofdifferentconditions of connectivity, Pivello et al. (2006) showed that the connectivity between large and small fragments interferes with community structure. According to the results, there was a contrast between the effects of landscape connectivity and vegetation structure since the reduction of connectivity between the studied fragments caused changes in the spatial configuration of the landscape and the habitat and dispersion syndrome of the species. 
When considered together, the landscape metrics of the present study permitted the description of landscape structure and the evaluation of the area from the point of view of preservation and conservation of classes of vegetation. According to the landscape metrics calculated herein, it was clear that the landscape structure was negatively affected due to an increased fragmentation from 1979 to 2015.

According to the presented results, one can conclude that the landscape metrics, when analyzed together, enabled the characterization of the landscape structure and the evaluation of the area, from the point of view of the preservation and conservation of the vegetation classes. According to the calculated landscape metrics, due to the increase in the number of small fragments of the area, the intensity of the edge effect was greater, and the reduction of the connectivity between the fragments indicates the need to create public policies that encourage the formation of ecological corridors in the area.

\section{ACKNOWLEDGMENTS}

This material is based upon dissertation work supported by the Coordenação de Aperfeiçoamento de Pessoal de Nível Superior (CAPES). I offer my gratitude to Erik Wild, Dr. Felice Shore and Suzane Abrantes, persons who helped me prepare the manuscript with writting assistance.

\section{REFERENCES}

ASSUNÇÃO SL AND FELFILI JM. 2004. Fitossociologia de um fragmento de cerrado sensu stricto na APA do Paranoá, DF, Brasil. Acta Bot 18: 903-909.

BARBOSA EG, PIVELLO VR AND MEIRELLES ST. 2008. Allelopathic evidence in Brachiaria decumbens and its potential to invade the Brazilian Cerrados. Braz Arch Biol Technol 51: 835-831.

BOLFE EL, PEREIRA RS, MADRUGA PRA AND FONSECA EL. 2004. Digital Classification Assessment of Forest Stands in Satellite Images Using Accuracy Indices. Árvore 28: 85-90.
BUREL F AND BAUDRY J. 2002. Landscape Ecology: Concepts, Methods and Applications. Science Publishers, Inc. USA: Enfield, 357 p.

CABACINHA CD, CASTRO SS AND GONÇALVES DA. 2010. Landscape structure analysis of the upper Araguaia river basian in the Brazilian Savanna. Floresta 40: 1-16.

CARMO AB, VASCONCELOS HL AND ARAÚJO GM. 2011. Structure of the woody plant community in fragments of Cerrado: relationship with fragment size and its level of disturbance. Rev Bras Bot 34: 31-38.

CARVALHO GGP AND PIRES AJV. 2008. Herbaceous Tropical Legumes Associated with Pasture Arch Zootec 57: 103-113.

DURIGAN G, COTIERI WA, FRANCO GAD AND GARRIDO MA. 1998. Inducement of Cerrado regeneration in a pasture area, Assis, SP. Acta Bot Bras 12: 421-429.

FERRAZ SFB AND VETTORAZZI CA. 2003. Identification of Suitable Areas for Forest Recovery Based on Principles of Landscape Ecology. Árvore 27: 575-583.

FORMAN RTT. 1995. Land mosaics: the ecology of landscapes and regions. Cambridge University Press, Cambridge.

FORMAN RTT AND GODRON M. 1986. Landscape Ecology. J Willy \& Sons, New York, 619 p.

GOERL RF, SIEFERT CAS, SCHULTZ GB, SANTOS CS AND SANTOS I. 2011. Development and Application of Landscape Fragmentation and Connectivity Index to Watershed Analysis. R Bras Geogr 4: 1000-1012.

GOMIDE LR AND LINGNAU C. 2008. Spatial simulation analysis of the landscape under edge effect. Floresta 39: 441-455.

HOFFMANN WA AND MOREIRA A. 2002. The role of fire in population dynamics of woody plants. In: Oliveira PS and Marquins RS (Eds), Ecology and Natural History of a Neotropical Savanna: The Cerrados of Brazil. Columbia University Press, p. 159-177.

JUVANHOL RS, FIEDLER NC, SANTOS AR, PIROVANI DB, LOUZADA FLRO, DIAS HM AND TEBALDI ALC 2011. Spatial Analysis of Forest Fragments: Case of the State Parks of Forno Grande and Pedra Azul, State of Espírito Santo. Floram 4: 353-364.

KLINK CA AND MACHADO RB. 2005. A Conservação do Cerrado Brasileiro. Megadiversidade 1: 1-9.

KÖPPEN W. 1900. Versuch einer Klassifikation der Klimate, vorzugsweisenach ihren Beziehungen zur Pflanzenwelt. Geographische Zeitschrift 6: 593-611.

LANG S AND BLASCHKE T. 2009. Landscape Analysis with GIS. $1^{\text {st }}$ ed., Oficina de Textos, São Paulo.

METZGER JP. 2001. O que é ecologia de paisagem? Biota Neotrop 1: 1-9.

MORAES MCP, MELLO K AND TOPPA RH. 2015. Análise da paisagem de uma zona de amortecimento como subsídio para o planejamento e gestão de unidades de conservação. Árvore 39: 1-8. 
MULLER A, BATAGHIN FAAND SANTOS SC. 2009. Efeito de borda sobre a comunidade arbórea em um fragmento de Floresta Ombrófila Mista, Rio Grande do Sul, Brasil. Perspectiva, Erechim 34: 29-39.

NASCIMENTO HEM AND LAURANCE WF. 2006. Area and edge effects on forest structure in Amazonian forest fragments after 13-17 years of isolation. Acta Amaz 36: 183-192.

PANIZZAAC AND FONSECA FP. 2011. Techniques of visual image interpretation. GeoUSP 30: 30-43.

PIROVANI DB, SILVA AG, SANTOS AR, CECÍLIO RA, GLERIANI JM AND MARTINS SV. 2014. Análise espacial de fragmentos florestais na bacia do rio Itapemirim, ES. Árvore 38: 271-281.

PIVELLO VR, PETENON D, JESUS FM, MEIRELLES ST, VIDAL MM, ALONSO RAS, FRANCO GADC AND METZGER JP. 2006. Seed rain in Atlantic forest fragments (São Paulo State, SP, Brazil) with different connectivity, forest structure and distance to edge. Acta Bot Bras 20: 845-859.

RIBEIRO MSL. 2008. Edge effects on vegetation and population structure in Cerradão fragments of Southwest Goiás, Brazil. Acta Bot Bras 22: 535-545.
RUDORFF CM, RIZZI R, RUDORFF BFT, SUGAWARA LM AND VIEIRA CAO. 2007. Spectral-temporal response surface of MODIS sensor images for soybean area classification in Rio Grande do Sul State. Cien Rural 37: 118-125.

SCARIOT A. 2000. Seedling mortality by litterfall in Amazonian forest fragments. Biotropica 32: 662-669.

SILVA CR, BARBOSA JM, CARRASCO PG, CASTANHEIRA AS, PEREIRA MA AND SANTOS JNA. 2009. Seed Rain in a High Sandbank Forest in Ilha Comprida (SP). Cerne 15: 355-365.

SKOLE DL AND TUCKER CJ. 1993. Tropical deforestation and habitat fragmentation in the Amazon: satellite data from 1978 to 1988. Science 260: 1905-1910.

VIANA VM AND PINHEIRO LAFV. 1998. Conservação da biodiversidade em fragmentos florestais. Série Técnica Ipef 12: 25-42.

VIDOLIN GP, BIONDI D AND WANDEMBRUCK A. 2011. Analysis of the landscape structure in a remaining fragment of forest with Araucaria in Paraná, Brazil. Árvore 35: 515-525.

ZUIDEMA PA, SAYER JA AND DIJKMAN W. 1996. Forest fragmentation and biodiversity: the case for intermediatesized conservation areas. Environ Conserv 23: 290-297. 